\title{
Chapter 17 \\ Environmental, Health and Equity Effects of Urban Green Space Interventions
}

\author{
Ruth F. Hunter, Anne Cleary, and Matthias Braubach
}

\begin{abstract}
As populations become increasingly urbanised, the preservation of urban green space becomes paramount. Despite the potential from cross-sectional evidence, we know little about how to design new, or improve or promote existing, urban green space for environmental, health and well-being benefits. This chapter highlights aspects to be considered when designing and evaluating urban green space interventions that aim to maximize environmental, social and health benefits, and address equity issues. Based on a review of international research evidence and a compilation of European case studies, the chapter addresses the variety of green space intervention approaches and their related impacts. There was strong evidence to support park-based and greenway/trail interventions employing a dual-approach (i.e. a physical change to the urban green space and promotion/marketing programmes particularly for park use and physical activity); strong evidence for the greening of vacant lots for health, well-being (e.g. reduction in stress) and social (e.g. reduction in crime) outcomes; strong evidence for the provision of urban street trees and green infrastructure for storm water management for environmental outcomes (e.g. increased biodiversity, reduced air pollution, climate change adaptation). Urban green space has an important role to play in creating a culture of health and well-being. Results show promising evidence to support the use of certain urban green space interventions for health, social and environmental benefits. The findings have important implications for policymakers, practitioners and researchers.
\end{abstract}

\footnotetext{
R. F. Hunter ( $\square)$

UKCRC Centre of Excellence for Public Health/Centre for Public Health, Queen's University

Belfast, Belfast, Northern Ireland, UK

e-mail: ruth.hunter@qub.ac.uk
}

\author{
A. Cleary \\ School of Medicine, Menzies Health Institute Queensland, Griffith University, \\ Gold Coast, Queensland, Australia \\ e-mail: anne.cleary@griffithuni.edu.au \\ M. Braubach \\ European Centre for Environment and Health, WHO Regional Office for Europe, \\ Bonn, Germany \\ e-mail: braubachm@who.int
}


Keywords Urban green space · Interventions · Health · Well-being · Environment - Equity

Highlights We know little about how to design new, or improve or promote existing, urban green space for health and social outcomes.

- Interventions should employ a dual approach that incorporates promotion and marketing of urban green space as well as changing the physical environment.

- There is evidence to support a range of environmental, health and social benefits.

- Little is known about the equity impact of urban green space interventions.

\subsection{Introduction}

The links between green space and health are increasingly well understood and have been summarised in numerous publications (Frumkin et al. 2017; WHO 2016). More than half of the world's population lives in urban areas (i.e. towns and cities), and this number is projected to increase to two in three people by 2050. Providing adequate green space within urban areas is therefore paramount. We need to preserve, enhance and promote existing urban green spaces and create new ones. Of course, for green space to provide its intended benefits it must be maintained and well cared for. Certain types of green space, such as vacant lots, have well-reported negative impacts (Branas et al. 2011).

Various political frameworks underscore the need for suitable green spaces in our cities. For example, the New Urban Agenda calls for an increase in safe, inclusive, accessible, green and quality public spaces. Similarly, the 2030 Agenda for Sustainable Development pledges to "provide universal access to safe, inclusive and accessible, green and public spaces, in particular, for women and children, older persons and persons with disabilities" (see Heiland et al. Chap. 19, this volume, for more on landscape planning legislation).

However, despite this growing interest in and support for urban green space, current knowledge is reasonably limited regarding the effectiveness of interventions related to the environment, health, well-being and equity. The evidence of the impact of such interventions on biodiversity and climate change adaptation is particularly scarce. This may be because there is limited understanding of the mechanisms through which green space might impact climate change. A previous review by the WHO Regional Office for Europe investigated the various mechanisms through which urban green space impacts human health (WHO Regional Office for Europe 2016), including by improving mental health and reducing the risk of cardiovascular disease, obesity, type II diabetes and cancer. Purported mechanisms 
included increased physical activity, reduced exposure to air and noise pollution, and psychological relaxation. However, the mechanisms through which urban green space impacts climate change are much less understood.

To address the gaps in our understanding on the effectiveness of urban green space interventions, the WHO Regional Office for Europe gathered experts on green space and urban planning to discuss approaches to and experiences with urban green space interventions. Based on a review of international research evidence and a compilation of European case studies (WHO Regional Office for Europe 2017), the expert meeting addressed the variety of green space intervention approaches and their related impacts on environmental conditions, health status, social and mental well-being, and equity. This chapter outlines the findings from this research, highlighting aspects to be considered when designing and evaluating urban green space interventions that aim to maximize environmental, social and health benefits and to address equity issues.

\subsection{Urban Green Space Interventions}

\subsubsection{What Are Urban Green Space Interventions?}

Urban green spaces are considered to be urban spaces covered by vegetation of any kind. This includes smaller green space features (such as street trees and roadside vegetation), green spaces not available for public access or recreational use (such as green roofs and facades, or green space on private grounds), and larger green spaces that provide various social and recreational functions (such as parks, playgrounds or greenways).

Urban green space interventions are defined as urban green space changes that significantly modify green space availability and features by creating new green space, changing or improving existing green space, or removing or replacing green space. The use of the term 'urban green spaces' should not be considered to conflict with other commonly used terms and definitions, such as 'green infrastructure', 'green corridors' or 'public open space', which tend to be applied in urban and regional planning.

On the basis of the evidence review, four main categories of urban green space interventions were identified:

1. Park-based: Involve change to the physical environment only, or use a dual approach combining a change to the physical environment with programming or marketing events in order to promote use of parks.

2. Greenways/trails: Development of new greenways (typically continuous linear corridor of green space facilitating walking, cycling and other activities) and walking/cycling trails, or the modification of existing greenways or walking/ cycling trails, for example, through the addition of signage, or using a dual approach (see above). 
3. Greening: Generally aesthetic-based interventions including greening of vacant lots (typically involving removing rubbish, planting trees) and providing street trees.

4. Green infrastructure: For environmental purposes such as storm water management or cooling urban/suburban areas, representing benefits related to the ecosystem service approach (provisioning and regulation of environmental goods and services).

These four categories, while not considered to be exhaustive or absolute, broadly represent the majority of green space interventions currently being applied in urban settings.

The methodologies for undertaking the evidence and case-study reviews are detailed elsewhere (WHO Regional Office for Europe 2017). Briefly, the evidence review searched eight electronic databases (Medline, PsycINFO, Web of Science (Science and Social Science Citation Indices), PADDI (Planning Architecture Design Database Ireland), Zetoc, Scopus, Greenfiles, SIGLE (System for Information on Grey Literature in Europe)). Studies were included if they: (i) evaluated an urban green space intervention; and (ii) measured health, well-being, social or environmental outcome(s). Interventions involving any age group were included. Interventions must have involved: (i) physical change to green space in an urbancontext including improvements to existing urban green space or development of new urban green space, or (ii) a combination of physical change to urban green space supplemented by a specific urban green space awareness, marketing or promotion programme to encourage use of urban green space. The case studies were submitted to the WHO in response to a call on urban green space interventions. An online survey questionnaire was used to gather data on characteristics of green space, type of intervention, project objectives and outcomes, impacts of the interventions, and lessons learned.

A summary of the evidence base for each intervention category and equity impacts, and case study examples illustrating intervention approaches are provided below.

\subsubsection{Park-Based Interventions}

There was strong evidence to support the use of park-based interventions that specifically combined a physical change to green space and promotion/marketing programmes, particularly for increasing park use and encouraging physical activity (7/7 studies showing a significant intervention effect) (see Table 17.1). A number of the studies in the review included control groups. Control groups allow researchers to assess whether the findings from the intervention tested are due solely to the intervention and help rule out alternate explanations. Typically control groups included green space sites that did not undergo any intervention (e.g. no change to the physical environment, and no new marketing events) during the study period, 


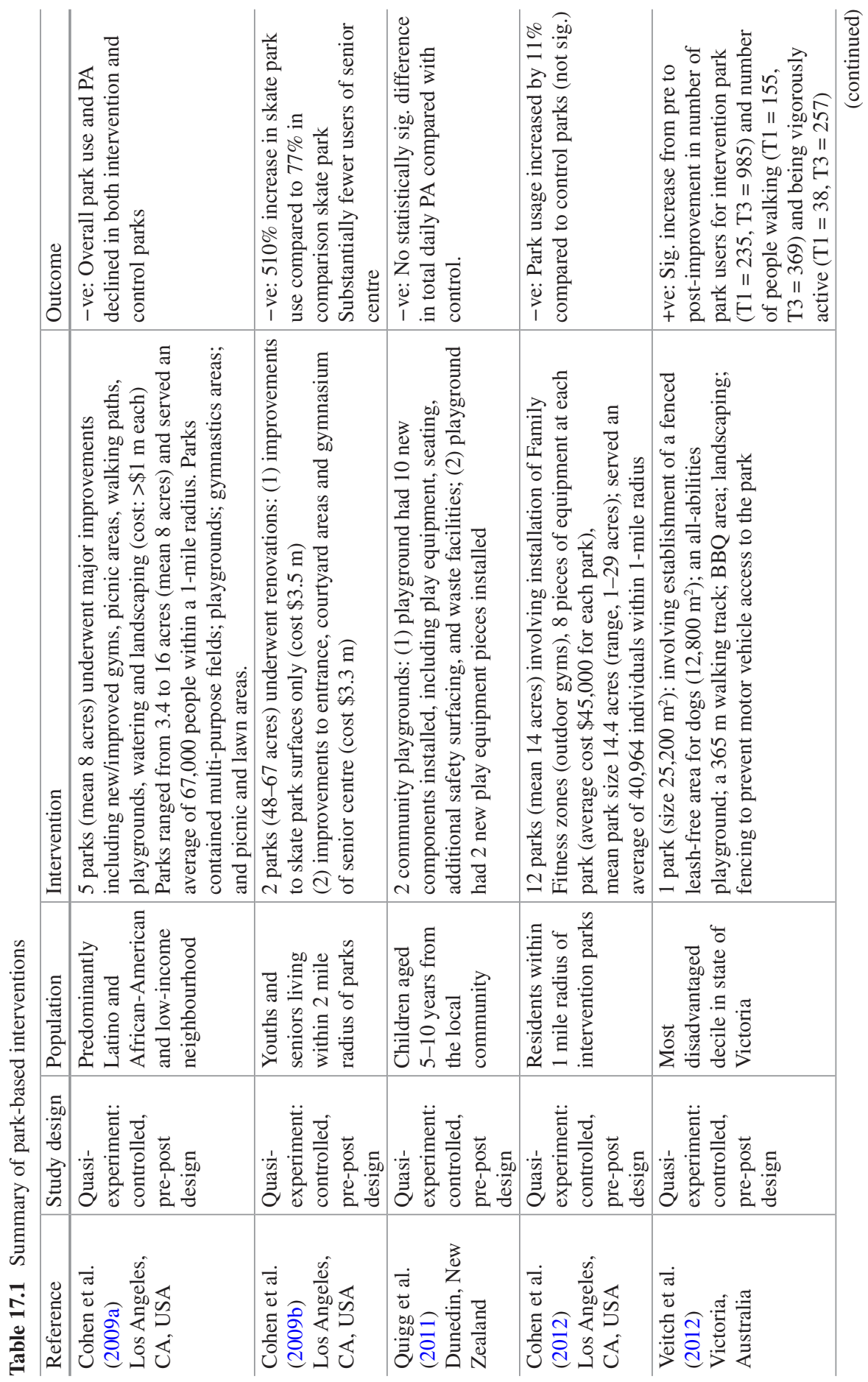




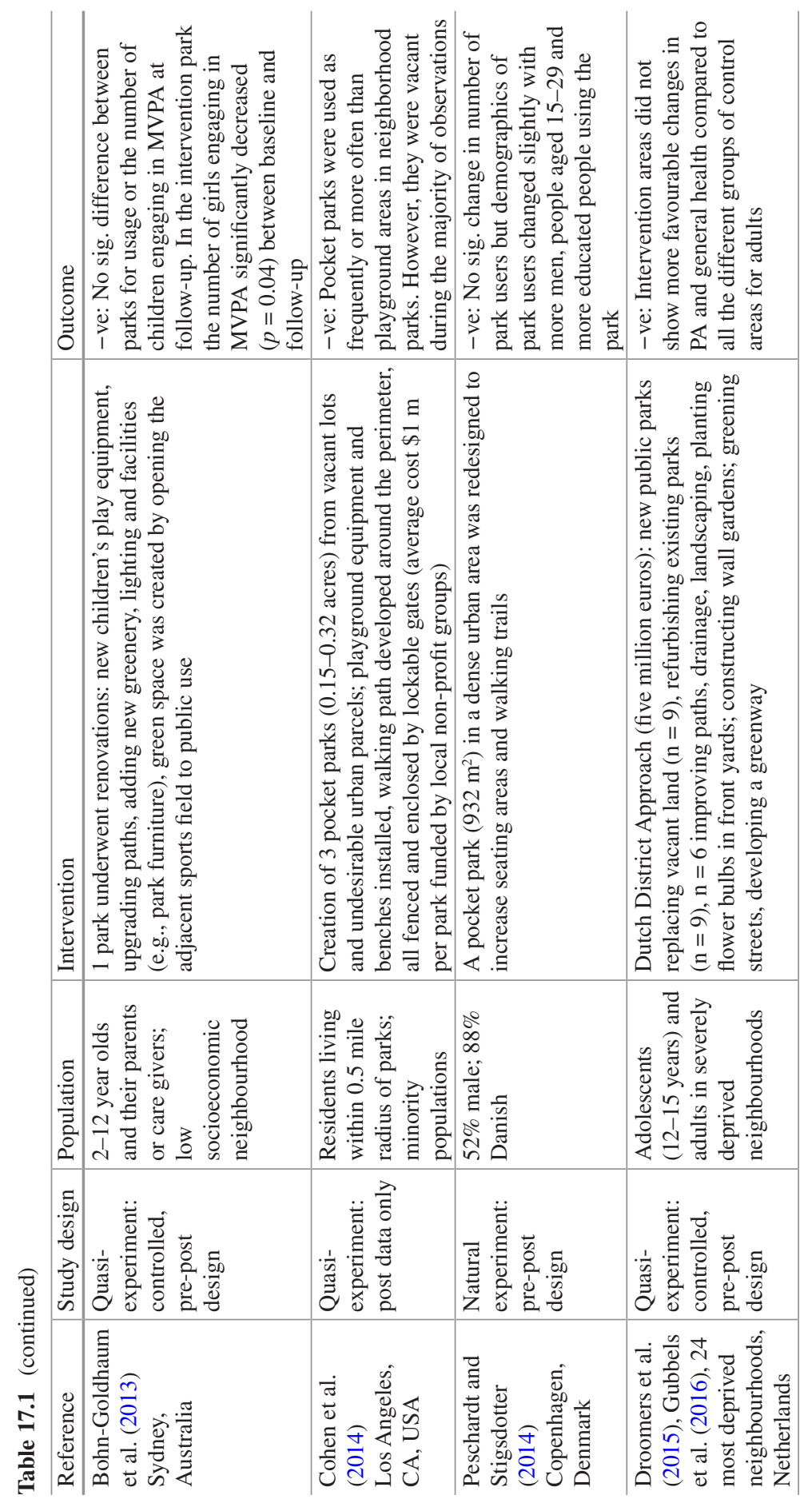




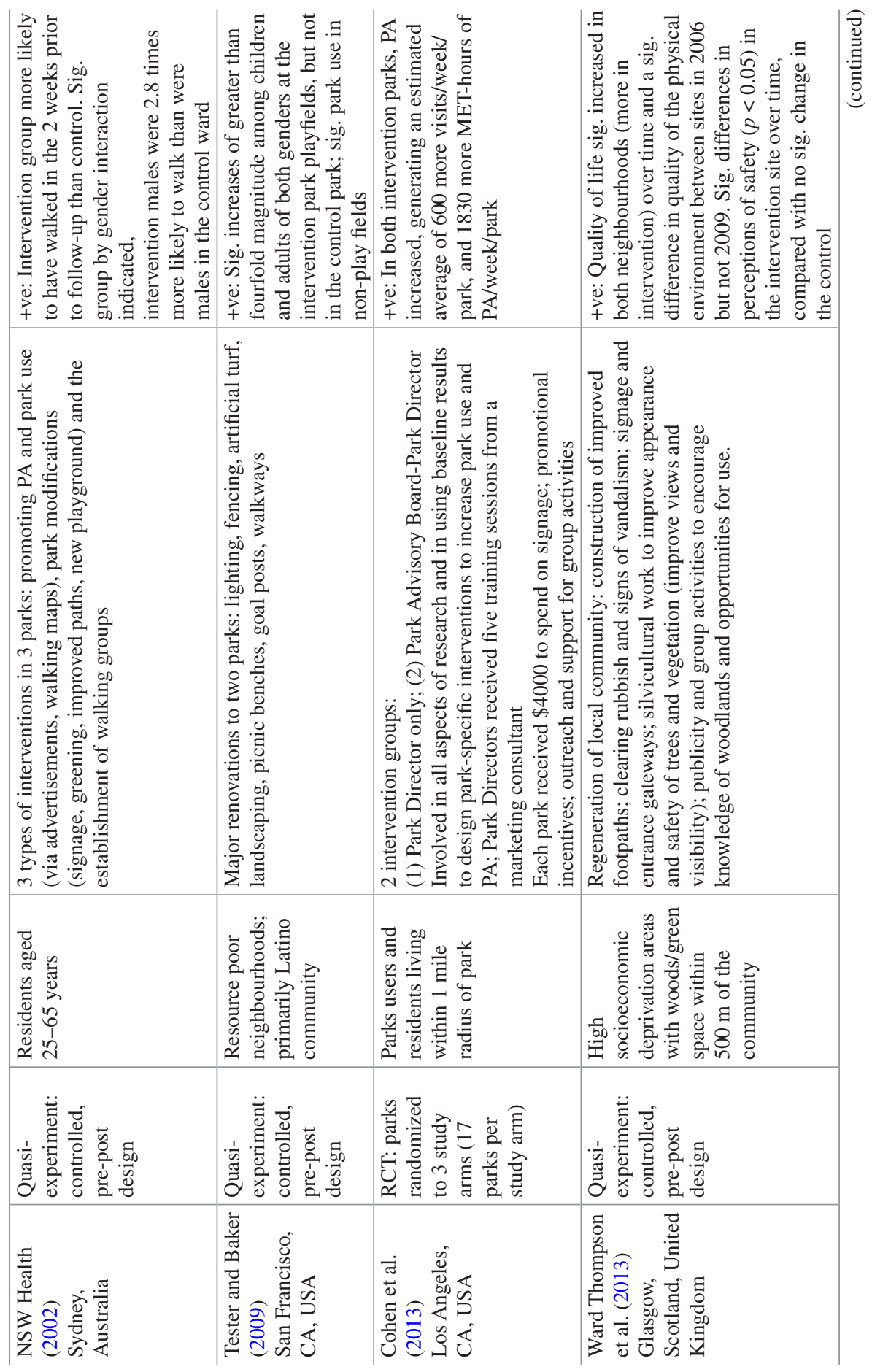




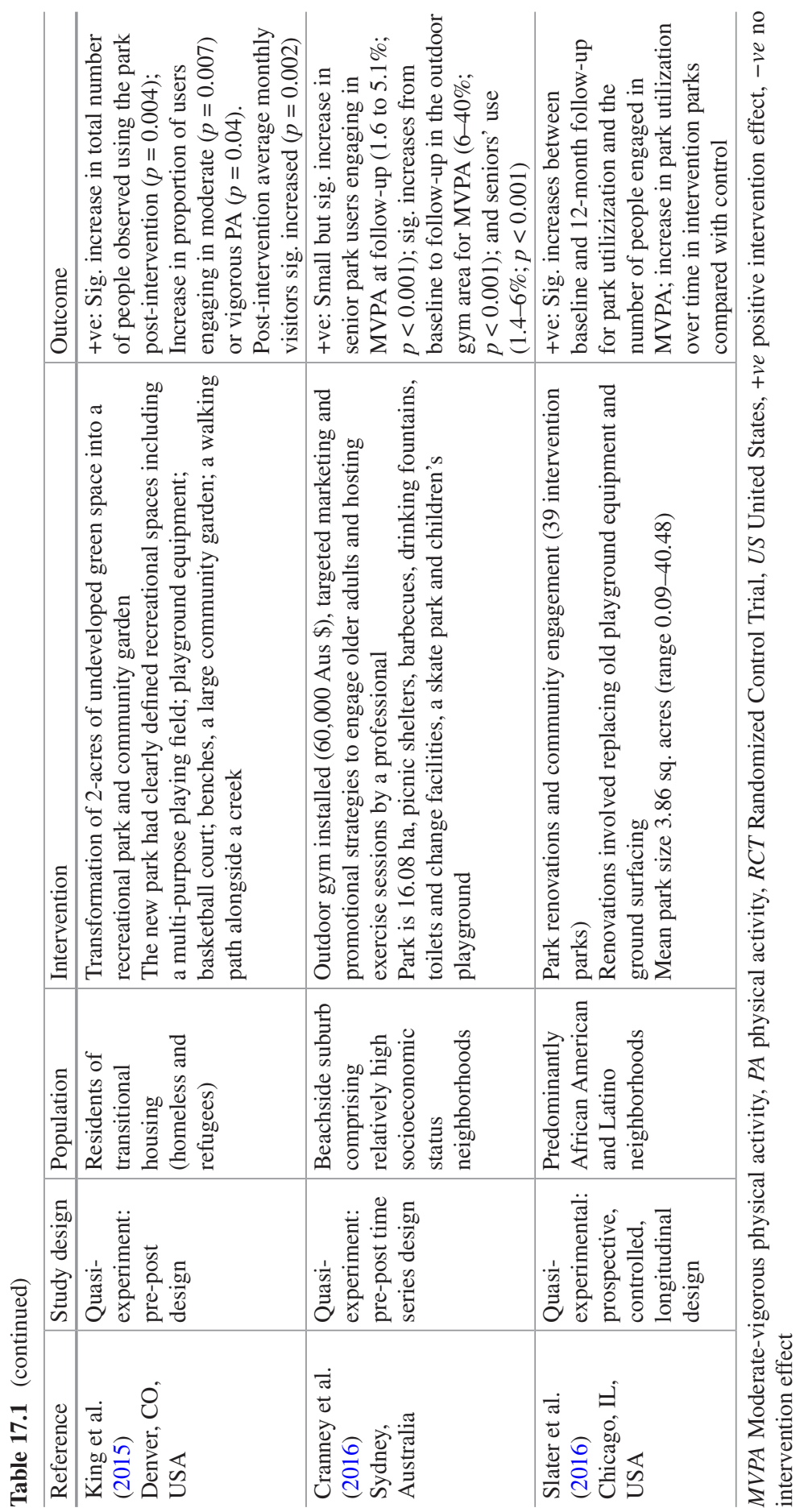


but the green space was similar in size, with similar characteristics, and served a similar population to the intervention site.

Four studies that involved major park improvements coupled with promotion programmes showed a significantly positive post-intervention effect for: increasing usage (Tester and Baker 2009; Ward Thompson et al 2013; King et al 2015; Slater et al 2016); physical activity (Tester and Baker 2009; King et al 2015; Slater et al 2016); quality of life (Ward Thompson et al. 2013); and perception of safety (Ward Thompson et al. 2013). Tester and Baker (2009) evaluated the effects of major improvements to playing fields of two public parks as well as physical activity programmes, and training and skills development for park and recreation programme staff. Results showed that playing field improvements, with and without family and youth involvement initiatives, significantly increased visitation and overall physical activity (four- to ninefold increase) compared to the control group. Ward Thompson et al. (2013) investigated the impact of regeneration of deprived areas in Glasgow, UK. Green spaces were upgraded through clearing rubbish and signs of vandalism; construction of improved footpaths, installation of signage and entrance gateways; and publicity and organization of group activities to encourage opportunities for use. Quality of life $(p=0.002)$, perceptions of safety $(p<0.05)$ and usage $(p<0.001)$ significantly improved among local residents compared with the control site. King et al. (2015) demonstrated significant improvements in park usage $(p=0.004)$ and physical activity of users $(p=0.007)$ after the transformation of 2 acres of undeveloped green space into a recreational park (including footpaths, playing fields, benches and basketball courts) and a community garden in an area of transitional housing for the homeless and refugees.

Slater et al. (2016) showed significant improvements in park usage and physical activity levels of users over time (up to 12 months) in 39 intervention parks that undertook major improvements including replacement of old playground equipment and ground surfacing, coupled with extensive community engagement activities to encourage and promote park usage, compared with control sites.

Three studies showed significant intervention effects for minor park improvements including significant increases in walking (NSW Health 2002), park usage and physical activity of users (Cohen et al. 2013; Cranney et al. 2016). An intervention in Sydney (NSW Health 2002) involved park modifications (e.g. signage, greening, improved paths and a new playground), park promotion use via advertisements, walking maps and the establishment of walking groups. A large randomised controlled trial (RCT) by Cohen et al. (2013) involved 51 parks allocated to one of three management trials. Park Directors received training from marketing consultants regarding outreach, customer service and promotion events. Each park received $\$ 4000$ to spend on park programmes, which included signage (e.g. banners, walking path signs), promotional incentives (e.g. water bottles, park-branded key chains, individually targeted e-mails), and outreach activities (e.g. hiring community engagement officers, buying activity materials). Cranney et al. (2016) investigated the effects of the provision of an outdoor gym in Sydney alongside hosting exercise sessions and targeted marketing and promotional strategies to engage older adults. 
There was a small but significant increase in senior green space users engaging in moderate-vigorous physical activity at follow-up $(1.6-5.1 \% ; p<0.001)$.

There was limited evidence regarding park-based interventions that only involved physical change to the green space (2/9 studies showed a significant intervention effect).

Two studies showed a positive outcome with increases in physical activity and park usage (Cohen et al. 2009b; Veitch et al. 2012). Cohen et al. (2009b) investigated the impact of two interventions that saw improvements made to a skate park and the green space surrounding a senior centre. Results showed a significant increase in skate park use but substantially fewer users of the green space surrounding the senior centre. There was also a significant increase in the perception of safety in both of the renovated green spaces $(p<0.001)$. An Australian study by Veitch et al. (2012) showed significant increases in the number of park users and number of people walking and being vigorously active after major park improvements (i.e. fenced leash-free area for dogs, playground, walking track, barbeque area and landscaping).

Seven studies showed no significant impact on physical activity, park usage or general health for urban green space interventions involving change to the built environment only (Cohen et al 2009a, 2012, 2014; Quigg et al 2011; BohnGoldhaum et al 2013; Peschardt and Stigsdotter 2014; Droomers et al 2015; Gubbels et al 2016). Cohen et al. (2009a) showed that park use and physical activity declined in parks that underwent major improvements including new/improved gyms, picnic areas, walking paths, playgrounds, watering and landscaping. A study by Quigg et al. (2011) investigated the impact of upgrading two community parks on children aged 5-10 years. Upgrades that involved installation of new play equipment, seating, additional safety surfacing, and waste facilities produced no change in physical activity levels among children.

Cohen et al. (2012) found that park usage increased by $11 \%$ compared to control parks (not statistically significant) following the installation of Family Fitness zones (i.e. outdoor gyms) in 12 parks.

The URBAN 40 study investigated the impact of changes in the quality or quantity of green space in different populations in 24 severely deprived neighbourhoods in the Netherlands. The intervention involved a suite of park-based and greening interventions (costing $€ 5$ million) to ameliorate problems with employment, education, housing, social cohesion and safety. The interventions involved: (i) provision of new public parks (from pocket parks up to 250 acres; $n=9$ ), and (ii) renovating existing parks $(n=9)$. Renovations of existing parks involved: improving paths, drainage, landscaping and maintenance; planting flower bulbs in front yards; constructing wall gardens; greening streets, and/or developing a greenway. Investments were made in green space that could be utilised by residents for recreation ('green to be used') and improvements in the green appearance of the neighbourhood ('green character'). Eighteen neighbourhoods improved their parks, in half of the cases in combination with investments in the green character of the neighbourhood. Nine of these neighbourhoods invested in new public parks. The other nine neigh- 
bourhoods redeveloped and refurbished existing parks. Another six neighbourhoods improved only their green character (no parks). Repeated cross-sectional surveys from 2004 until 2011 yielded self-reported information on leisure-time walking, cycling and sports, perceived general health and mental health, of over 48,000 local residents. Results showed that the intervention sites did not show more favourable changes in physical activity and general health compared to all the different groups of control areas (Droomers et al. 2015). In a subset of these neighbourhoods, additional data were collected from the same individuals before and after the interventions (Gubbels et al. 2016). Also in this study, no significant health-related improvements were associated with the interventions, with two exceptions. Objective improvements in greenery were associated with a smaller decline in adolescents' leisure time cycling, and improvements in perceived greenery were related to a decrease in adults' depressive symptoms.

There was no evidence to support the provision of pocket parks (typically small green spaces with limited facilities or programming, if any) for increased usage and physical activity (Cohen et al. 2014; Peschardt and Stigsdotter 2014). Cohen et al. (2014) investigated the impact of the creation of three pocket parks on the number of park users and physical activity. This involved installation of playground equipment and benches and development of walking paths, and all areas were fenced and enclosed by lockable gates. Results showed that pocket parks were used as frequently or more often than playground areas in neighbourhood parks (control areas); however, they were vacant during the majority of observations. The authors concluded that pocket parks may act as catalysts for physical activity; however, additional marketing and programmes may be needed to encourage usage. Similarly, Peschardt and Stigsdotter (2014), in a dense urban area, found no significant change in number of park users following the redesign of a pocket park that increased seating areas and walking trails.

\subsubsection{Greenways and Trail Interventions}

There was inconclusive evidence (3/6 studies showed a significant intervention effect) to support the use of new or modified trails or greenways for promoting health benefits (see Table 17.2).

Fitzhugh et al. (2010) investigated the impact of an urban greenway trail designed to enhance connectivity of pedestrian infrastructure with nearby retail establishments and schools. The study showed significant changes between the intervention and control neighbourhoods for total physical activity $(p=0.001)$, walking $(p=0.001)$ and cycling $(p=0.038)$. A study in the USA (Clark et al. 2014) showed significantly positive effects for a marketing campaign and addition of signage for trail use. Usage of ten urban trails (six intervention and four control trails) were monitored following a marketing campaign promoting trail use and the addition of way-finding and incremental distance signage to selected trails. 
Significant pre-post increases in trail usage were found for both comparison ( $31 \%$ increase) and intervention (35\% increase) trails $(p<0.01)$. A large multisite natural experiment in the UK $(n=1796$ participants $)$ investigated the impact of new walking and cycling routes on physical activity (Sahlqvist et al. 2013; Brand et al. 2014; Goodman et al. 2014). Proximity to the intervention was strongly associated with greater use of the new infrastructure $32 \%$ of the study population reported using the new infrastructure at 1-year follow-up; 38\% reported at 2-year

\section{Case Study: Parque Ribeiro do Matadouro, Santo Tirso, Portugal}

Led by the Santo Tirso municipality, the 'Parque Ribeiro do Matadouro' is a 1.54 ha park constructed on derelict land, near the Matadouro stream, close to the Santo Tirso city centre. Construction of the park was completed in 2013 costing approximately $€ 1,400,000$. This park-based intervention applied a dual approach. Open public forums engaged local community in the design of the park with feedback and suggestions from the community being included in the design (e.g. wi-fi access in the park). Guided tours occurred during the construction phase to keep the community updated on progress of the park's construction and the park's name was chosen via community voting in a naming contest. Signs, interactive art installations and organised community events within the park invite people to visit and use the park. Further work is planned to expand green space along the river to create green networks improving connectivity between Parque Ribeiro do Matadouro and other green spaces. This phase of works will also closely integrate social engagement, with community gardens and a youth house being established as part of the intervention (Fig. 17.1).

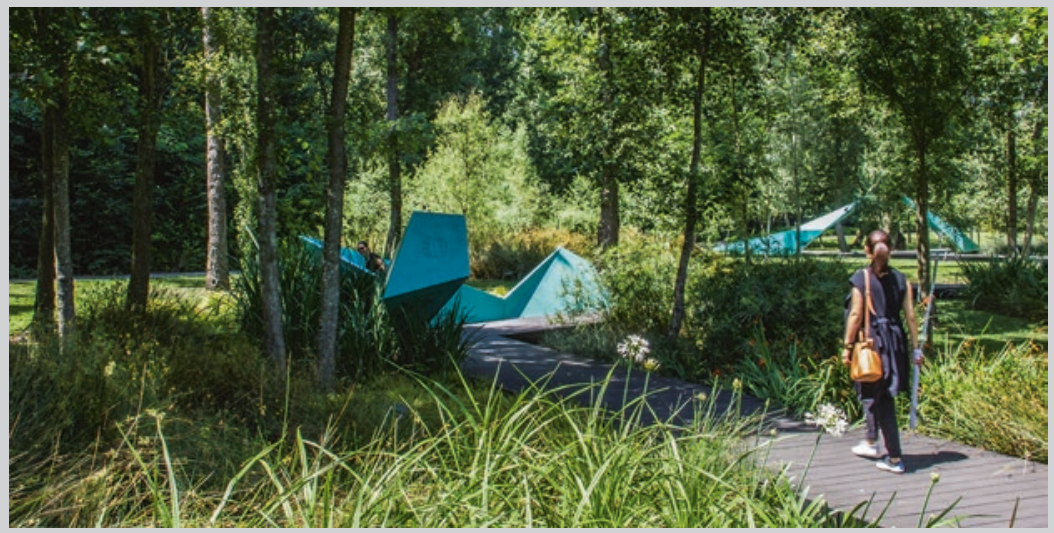

Fig. 17.1 Interactive art installations at Parque Ribeiro do Matadouro invite visitors to engage with the space. (Image: Victor Esteves, Oh!Land Studio) 
Table 17.2 Summary characteristics of greenway and trail interventions

\begin{tabular}{|c|c|c|c|c|}
\hline Reference & Study design & Population & Intervention & Outcome \\
\hline $\begin{array}{l}\text { Evenson et al. } \\
\text { (2005) } \\
\text { North } \\
\text { Carolina, USA }\end{array}$ & $\begin{array}{l}\text { Quasi- } \\
\text { experimental: } \\
\text { pre-post } \\
\text { design }\end{array}$ & $\begin{array}{l}\text { Adults aged } \\
>18 \text { years living } \\
\text { within } 2 \text { miles of } \\
\text { the trail }\end{array}$ & $\begin{array}{l}\text { A railway was } \\
\text { converted to a } \\
\text { multi-use trail } \\
\text { Trail } \\
2.8 \text { miles } / 10 \text { feet } \\
\text { wide with } 2 \text { mile } \\
\text { spur of } 23 \text { mile trail; } \\
\text { trail passed by } 2 \\
\text { schools, shopping } \\
\text { areas, apartment } \\
\text { buildings and } \\
\text { neighbourhoods }\end{array}$ & $\begin{array}{l}\text {-ve: Those who had } \\
\text { never used the trail } \\
\text { had sig. declines in } \\
\text { median time spent in } \\
\text { MVPA, vigorous PA } \\
\text { and bicycling for } \\
\text { transport. Those who } \\
\text { had used the trail } \\
\text { also had sig. declines } \\
\text { in median time spent } \\
\text { in vigorous PA. }\end{array}$ \\
\hline $\begin{array}{l}\text { Burbidge and } \\
\text { Goulias (2009) } \\
\text { Utah, USA }\end{array}$ & $\begin{array}{l}\text { Quasi- } \\
\text { experiment: } \\
\text { longitudinal } \\
\text { design }\end{array}$ & $\begin{array}{l}\text { Individuals } \\
\text { residing near the } \\
\text { new trail }\end{array}$ & $\begin{array}{l}\text { Construction of a } \\
\text { trail (2-way } \\
\text { multi-use trail } \\
\text { separated from } \\
\text { existing roads and } \\
\text { sidewalks) for both } \\
\text { transportation and } \\
\text { recreation. The trail } \\
\text { created a } 2.5 \text { mile } \\
\text { loop connecting two } \\
\text { currently existing } \\
\text { sidewalks }\end{array}$ & $\begin{array}{l}\text {-ve: Negative sig. } \\
\text { effect on PA and } \\
\text { walking between } \\
\text { baseline and } \\
\text { follow-up; } \\
\text { 18-64 year olds sig. } \\
\text { increased number of } \\
\text { PA episodes between } \\
\text { baseline and } \\
\text { follow-up } \\
(p=0.024)\end{array}$ \\
\hline $\begin{array}{l}\text { Fitzhugh et al. } \\
(2010) \\
\text { Tennessee, } \\
\text { USA }\end{array}$ & $\begin{array}{l}\text { Quasi- } \\
\text { experiment: } \\
\text { controlled, } \\
\text { pre-post } \\
\text { design }\end{array}$ & $\begin{array}{l}\text { Children, } \\
\text { adolescents and } \\
\text { adults in } \\
\text { neighbourhood }\end{array}$ & $\begin{array}{l}\text { Retrofit of an urban } \\
\text { greenway ( } 2.9 \text { miles } \\
\text { long; } 8 \text {-foot wide) to } \\
\text { enhance connectivity } \\
\text { of pedestrian } \\
\text { infrastructure with } \\
\text { nearby retail } \\
\text { establishments and } \\
\text { schools (cost: } \\
\$ 2.1 \mathrm{~m})\end{array}$ & $\begin{array}{l}\text { +ve: Pre and post } \\
\text { intervention changes } \\
\text { between } \\
\text { experimental and } \\
\text { control } \\
\text { neighbourhoods } \\
\text { were sig. different } \\
\text { for total PA } \\
(p=0.001) \text {; walking } \\
(p=0.001) \text { and } \\
\text { cycling ( } p=0.038) \text {. } \\
\text { There was no sig. } \\
\text { change over time for } \\
\text { active transport to } \\
\text { school }\end{array}$ \\
\hline $\begin{array}{l}\text { West and } \\
\text { Shores (2011) } \\
\text { North } \\
\text { Carolina, USA }\end{array}$ & $\begin{array}{l}\text { Quasi- } \\
\text { experiment: } \\
\text { controlled, } \\
\text { pre-post } \\
\text { design } \\
\end{array}$ & $\begin{array}{l}\text { Residents living } \\
\text { within } 0.5 \text { mile } \\
\text { radius of } \\
\text { greenway }\end{array}$ & $\begin{array}{l}5 \text { miles of greenway } \\
\text { developed and added } \\
\text { to existing greenway } \\
\text { along a river }\end{array}$ & $\begin{array}{l}\text {-ve: No sig. } \\
\text { difference between } \\
\text { intervention and } \\
\text { control group }\end{array}$ \\
\hline
\end{tabular}


Table 17.2 (continued)

\begin{tabular}{|c|c|c|c|c|}
\hline Reference & Study design & Population & Intervention & Outcome \\
\hline $\begin{array}{l}\text { Clark et al. } \\
\text { (2014) } \\
\text { Southern } \\
\text { Nevada, USA }\end{array}$ & $\begin{array}{l}\text { Quasi- } \\
\text { experiment: } \\
\text { controlled, } \\
\text { pre-post } \\
\text { design }\end{array}$ & $\begin{array}{l}\text { Trails were in } \\
\text { lower SES } \\
\text { neighbourhoods }\end{array}$ & $\begin{array}{l}6 \text { intervention trails: } \\
\text { after a marketing } \\
\text { campaign promoting } \\
\text { PA and trail use } \\
\text { (2012), signage was } \\
\text { added/altered } \\
\text { including: distance } \\
\text { markings, way- } \\
\text { finding signs, trail } \\
\text { maps, trail names, } \\
\text { and icons for } \\
\text { acceptable uses }\end{array}$ & $\begin{array}{l}\text { +ve: Sig. increases } \\
\text { for both control and } \\
\text { intervention, } \\
\text { pre-post for trail } \\
\text { usage per day; } 31 \% \\
\text { increase for the } \\
\text { control trails and } \\
35 \% \text { for the } \\
\text { intervention trails } \\
(p<0.01) \text {; non-sig. } \\
\text { difference between } \\
\text { the intervention and } \\
\text { control group } \\
(p=0.32)\end{array}$ \\
\hline $\begin{array}{l}\text { Brand et al. } \\
\text { (2014), } \\
\text { Sahlqvist et al. } \\
\text { (2013), Bird } \\
\text { et al. (2014), } \\
\text { Goodman et al. } \\
\text { (2014) } \\
\text { Cardiff, } \\
\text { Kenilworth and } \\
\text { Southampton, } \\
\text { United } \\
\text { Kingdom }\end{array}$ & $\begin{array}{l}\text { Quasi- } \\
\text { experimental, } \\
\text { longitudinal } \\
\text { design }\end{array}$ & $\begin{array}{l}\text { Adults living } \\
\text { within } 5 \mathrm{~km} \text { by } \\
\text { road of the core } \\
\text { Connect } 2 \\
\text { projects }\end{array}$ & $\begin{array}{l}\text { Building or } \\
\text { improvement of } \\
\text { walking and cycling } \\
\text { routes across the } \\
\text { United Kingdom } \\
\text { including a } \\
\text { traffic-free bridge } \\
\text { over Cardiff Bay; a } \\
\text { traffic-free bridge } \\
\text { over a busy trunk } \\
\text { road; an informal } \\
\text { riverside footpath } \\
\text { turned into a } \\
\text { boardwalk }\end{array}$ & $\begin{array}{l}\text { +ve: Proximity to } \\
\text { Connect } 2 \text { associated } \\
\text { with greater use of } \\
\text { Connect } 2 ; 32 \% \\
\text { reported using } \\
\text { Connect } 2 \text { at } 1 \text { year } \\
\text { and } 38 \% \text { at } 2 \text { years.; } \\
\text { at } 2 \text { years, those } \\
\text { nearer the } \\
\text { intervention sig. } \\
\text { increased walking } \\
\text { and cycling }(15.3 \\
\text { mins } / \text { week } / \mathrm{km}) \text { and } \\
\text { total PA }(12.5 \text { mins/ } \\
\text { week } / \mathrm{km})\end{array}$ \\
\hline
\end{tabular}

MVPA Moderate-vigorous physical activity, PA physical activity, US United States, +ve positive intervention effect, $-v e$ no intervention effect

follow-up). At 2-year follow-up individuals living nearer the intervention versus those living further away did report significant increases in walking and cycling (effect of 15.3 min per week per km closer to the intervention after adjustments for baseline variables). Proximity was also associated with a comparable increase in total physical activity (effect of 12.5 min per week per $\mathrm{km}$ closer to the intervention). Further analyses showed that the intervention did not produce reductions in $\mathrm{CO}_{2}$ emissions (Brand et al. 2014).

Three studies showed no significant impact for the provision of new trails/greenways on usage or physical activity. Evenson et al. (2005) found no significant effect for usage and physical activity on a new 2.8-mile (approx. 4.5-km) multiuse trail in the USA. Burbidge and Goulias (2009) found no significant effects for the construction of a multiuse trail designed for both active transport and recreational use. A study by West and Shores (2011) found no significant effect on physical activity 
behaviour for 5 miles (approx. $8 \mathrm{~km}$ ) of greenway developed and added to an existing greenway along a river. None of these interventions included any promotion or marketing campaign of the new trails/greenways.

\section{Case Study: Connswater Community Greenway, Belfast, Northern Ireland, UK}

Developed by the East Belfast Partnership and led by Belfast City Council, the Connswater Community Greenway provides $9 \mathrm{~km}$ of linear park running along the course of the Connswater, Knock and Loop Rivers. The project, which cost approximately $€ 47,000,000$, was funded through the Big Lottery Fund, Belfast City Council and the Department for Social Development. The intervention delivers multiple social and environmental outcomes through the provision of foot and cycle paths for physical activity, tourism and heritage trails, hubs for education, and elements of the East Belfast Flood Alleviation Scheme. Social engagement occurred in parallel with physical changes to the intervention site. A so-called 'bottom-up' approach was applied, which involved the employment of a full-time community support officer. This project also recognizes that green space interventions are long-term investments as reflected by the 40-year management and maintenance plan for the greenway that was developed from the outset (Fig. 17.2).

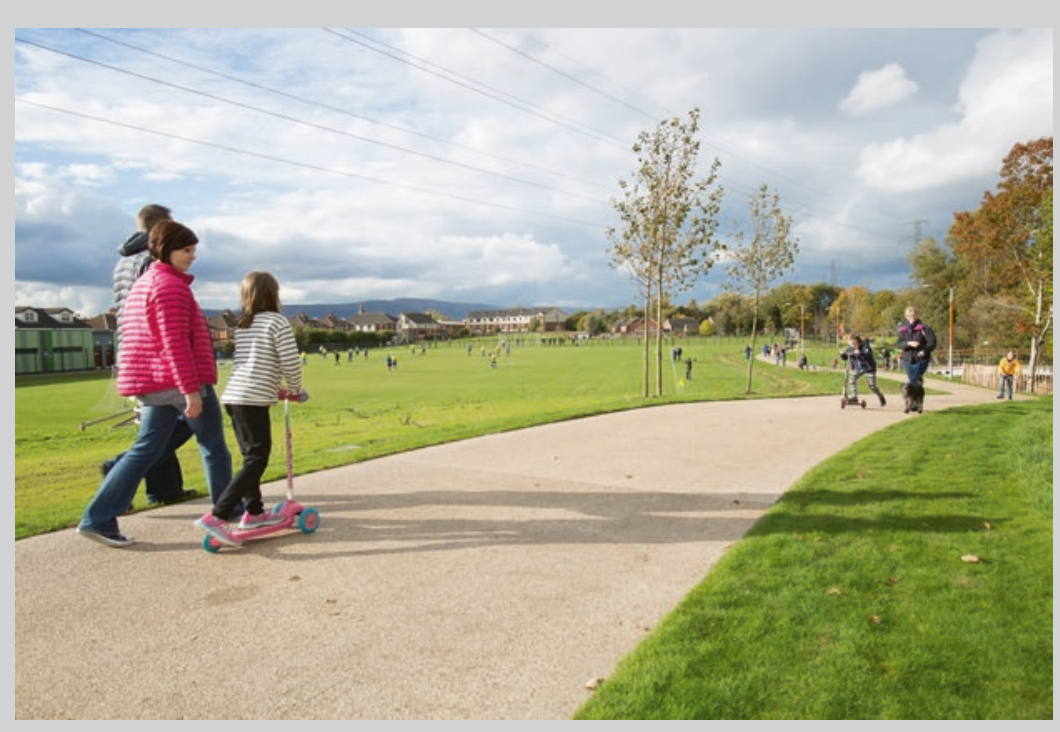

Fig. 17.2 Connswater Community Greenway delivers social and environmental outcomes. (Image: Connswater Community Greenway Trust) 


\subsubsection{Greening Interventions}

There was strong evidence to support the greening of vacant lots (4/4 studies showed a significant intervention effect) and greening of urban streets (4/4 studies demonstrated a significant intervention effect), for environmental, physiological, psychological and improved social environment outcomes (see Table 17.3).

A decade-long study using a difference-in-difference design in the USA (Branas et al. 2011) showed that greening of vacant urban lots $\left(>725,000 \mathrm{~m}^{2}\right)$ resulted in reductions in gun assaults $(p<0.001)$, vandalism $(p<0.001)$ and residents reporting less stress and more exercise $(p<0.01)$. In an RCT, Garvin et al. (2013) demonstrated a decrease in the number of total crimes and gun assaults, and increased safety around greened vacant lots compared with control lots $(p>0.05)$. Anderson et al. (2014) demonstrated significant biodiversity outcomes for a range of greening interventions in three deprived urban areas in South Africa. In a US-based study, South et al. (2015) found that heart rate lowered significantly in local residents living near greened compared to non-greened vacant lots $(n=2$ clusters of vacant lots) $(p<0.001)$.

Four (out of four) studies showed significant impacts on health and environmental factors for interventions involving greening of urban streets. Ward Thompson et al. (2014) found evidence to support the provision of so-called 'DIY streets' in urban areas in the UK. Streets were made safer and more attractive (e.g. planting trees/plants), and traffic calming measures were added at nine different sites. Longitudinal data showed that participants perceived they were significantly more active post-intervention $(p=0.04)$ than the comparison group, and there were significant improvements in perceptions of the environment. Joo and Kwon (2015) found that illegal dumping of household garbage occurred at $55.4 \%$ of greened sites $(n=74)$ compared to $91.9 \%$ of sites without greenery $(n=74)$ in South Korea. Strohbach et al. (2013) showed a significant increase in bird species in a study investigating 12 community-driven greening projects involving tree plantings carried out in deprived areas compared to random urban sites without greening $(\mathrm{p}=0.049)$. Adverse outcomes from greening interventions were also reported by Jin et al. (2014), who demonstrated that increased street tree canopy was positively associated with $\mathrm{PM}_{2.5}$ (particulate matter with aerodynamic diameters of $2.5 \mathrm{~mm}$ or less) concentrations owing to reduced air circulation.

\subsubsection{Green Infrastructure Interventions}

There was promising evidence to support the provision of rain gardens (3/4 studies showed a significant positive effect) and strong evidence to support the provision of roof gardens (3/3 studies showed a significant positive effect) for managing the adverse impact of storm water. One study (1/1 study) demonstrated significant cooling effects for a roof garden in a suburban area (see Table 17.4). 
Table 17.3 Summary characteristics of greening interventions

\begin{tabular}{|c|c|c|c|c|}
\hline Reference & Study design & Population & Intervention & Outcome \\
\hline $\begin{array}{l}\text { Branas et al. } \\
\text { (2011) } \\
\text { Philadelphia, } \\
\text { PA, USA }\end{array}$ & $\begin{array}{l}\text { Quasi- } \\
\text { experiment: } \\
\text { difference-in- } \\
\text { difference } \\
\text { design }\end{array}$ & $\begin{array}{l}\text { Cohort of 50,000 } \\
\text { Philadelphians } \\
\text { from household } \\
\text { survey }\end{array}$ & $\begin{array}{l}\text { Greening of vacant } \\
\text { urban land }(\mathrm{n}=4436) ; \\
\left(>725,000 \mathrm{~m}^{2}\right) \text { from } \\
1999 \text { to } 2008 \\
\text { involving removing } \\
\text { trash and debris, } \\
\text { grading the land, } \\
\text { planting grass and } \\
\text { trees, installing low } \\
\text { wooden fences around } \\
\text { perimeter }\end{array}$ & $\begin{array}{l}+ \text { ve: Greening } \\
\text { associated with } \\
\text { reductions in gun } \\
\text { assaults } \\
(p<0.001), \\
\text { vandalism } \\
(p<0.001), \\
\text { residents reported } \\
\text { less stress and } \\
\text { more exercise } \\
(p<0.01)\end{array}$ \\
\hline $\begin{array}{l}\text { Garvin et al. } \\
\text { (2013) } \\
\text { Philadelphia, } \\
\text { PA, USA }\end{array}$ & $\begin{array}{l}\text { Pilot RCT: } \\
\text { difference-in- } \\
\text { difference } \\
\text { analytical } \\
\text { approach }\end{array}$ & $\begin{array}{l}\text { People living } \\
\text { approx. two blocks } \\
\text { surrounding the } \\
\text { randomly selected } \\
\text { vacant lots; } 97 \% \\
\text { African-American; } \\
\text { median income } \\
\$ 15,417-17,743\end{array}$ & $\begin{array}{l}\text { Greening of vacant } \\
\text { lots (4500-5500 } \\
\text { square feet); removing } \\
\text { debris, grading the } \\
\text { land and adding } \\
\text { topsoil, planting grass } \\
\text { and trees, building a } \\
\text { wooden fence }\end{array}$ & $\begin{array}{l}\text { +ve: Non-sig. } \\
\text { decrease in the } \\
\text { number of total } \\
\text { crimes and gun } \\
\text { assaults around } \\
\text { greened vacant lots } \\
\text { compared with } \\
\text { control; people } \\
\text { around the } \\
\text { intervention lots } \\
\text { reported feeling } \\
\text { sig. safer after } \\
\text { greening compared } \\
\text { with control lots } \\
(p<0.01)\end{array}$ \\
\hline $\begin{array}{l}\text { Anderson } \\
\text { et al. (2014) } \\
\text { Cape Town, } \\
\text { South Africa }\end{array}$ & $\begin{array}{l}\text { Quasi- } \\
\text { experimental, } \\
\text { controlled } \\
\text { (post data } \\
\text { only) }\end{array}$ & $\begin{array}{l}\text { Spectrum of } \\
\text { socioeconomic } \\
\text { neighbourhoods, } \\
\text { ranging from } \\
\text { middle to lower } \\
\text { income areas }\end{array}$ & $\begin{array}{l}\text { Civic-led greening } \\
\text { interventions } \\
\text { implemented via three } \\
\text { sites }\end{array}$ & $\begin{array}{l}\text { +ive: Biodiversity } \\
\text { in the greening } \\
\text { intervention sites } \\
\text { was higher than } \\
\text { the vacant lot and } \\
\text { comparable to the } \\
\text { conservation sites }\end{array}$ \\
\hline $\begin{array}{l}\text { South et al. } \\
\text { (2015) } \\
\text { Philadelphia, } \\
\text { PA, USA }\end{array}$ & $\begin{array}{l}\text { Quasi- } \\
\text { experimental, } \\
\text { controlled, } \\
\text { pre and post }\end{array}$ & $\begin{array}{l}\mathrm{N}=12 \text { participants } \\
\text { completed pre- and } \\
\text { post-intervention } \\
\text { walks; all were } \\
\text { African-American, } \\
\text { eight male; } \\
\text { majority had } \\
\text { household income } \\
<\mathrm{S} 15,000\end{array}$ & $\begin{array}{l}\text { Randomly selected } \\
\text { cluster of vacant lots } \\
\text { received standard } \\
\text { greening treatment } \\
\text { involving cleaning and } \\
\text { removing debris, } \\
\text { planting grass and } \\
\text { trees, and installing a } \\
\text { low wooden post-and- } \\
\text { rail fence }\end{array}$ & $\begin{array}{l}\text { +ve: Difference-in- } \\
\text { difference } \\
\text { estimates between } \\
\text { greened and } \\
\text { non-greened } \\
\text { vacant lots was } \\
\text { sig. lower for heart } \\
\text { rate }(p<.001) \text { for } \\
\text { the greened site; } \\
\text { being in view of a } \\
\text { greened vacant lot } \\
\text { decreased } \\
\text { heart rate sig. more } \\
\text { than a non-greened } \\
\text { vacant lot }\end{array}$ \\
\hline
\end{tabular}


Table 17.3 (continued)

\begin{tabular}{|c|c|c|c|c|}
\hline Reference & Study design & Population & Intervention & Outcome \\
\hline $\begin{array}{l}\text { Strohbach } \\
\text { et al. (2013) } \\
\text { Boston, MA, } \\
\text { USA }\end{array}$ & $\begin{array}{l}\text { Quasi- } \\
\text { experimental, } \\
\text { controlled } \\
\text { (post data } \\
\text { only) }\end{array}$ & $\begin{array}{l}\text { Low SES areas; } \\
617,594 \\
\text { inhabitants; } \\
\text { population } \\
\text { density of } 4939 \\
\text { inhabitants per } \\
\mathrm{km}^{2} \text {; tree canopy } \\
\text { covers } 29 \% \text { of the } \\
\text { city area }\end{array}$ & $\begin{array}{l}12 \text { community driven } \\
\text { greening projects in } \\
\text { low SES areas } \\
\text { including creation of a } \\
\text { small park } \\
\left(424 \mathrm{~m}^{2}\right) \text {,tree plantings } \\
\text { in an existing park } \\
\left(4377 \mathrm{~m}^{2}\right) \text { and tree } \\
\text { plantings at residential } \\
\text { houses }\left(859 \mathrm{~m}^{2}\right)\end{array}$ & $\begin{array}{l}\text { +ve: Sig. } \\
\text { difference between } \\
\text { greening projects } \\
\text { and random urban } \\
\text { sites }(p=.049) ; \\
\text { most greening } \\
\text { projects had more } \\
\text { species than the } \\
\text { random urban sites } \\
\text { in their vicinity }\end{array}$ \\
\hline $\begin{array}{l}\text { Jin et al. } \\
(2014) \\
\text { Shanghai, } \\
\text { China }\end{array}$ & $\begin{array}{l}\text { Quasi- } \\
\text { experimental, } \\
\text { controlled } \\
\text { (post data } \\
\text { only) }\end{array}$ & $\begin{array}{l}\text { Area of } \\
6340.5 \mathrm{~km}^{2}, 23.5 \\
\text { million population }\end{array}$ & $\begin{array}{l}\text { Street trees on } 6 \\
\text { streets (length } \\
205-223 \text { m; width } \\
15.2-17.5 \text { m) were } \\
\text { treated with different } \\
\text { pruning intensities } \\
\text { (strong, weak and } \\
\text { null) which would } \\
\text { result in different } \\
\text { canopy coverage } \\
\text { across the four } \\
\text { seasons }\end{array}$ & $\begin{array}{l}\text { +ve: Increased } \\
\text { street tree canopy } \\
\text { was positively } \\
\text { associated with } \\
\mathrm{PM}_{2.5} \\
\text { concentrations } \\
\text { owing to reduced } \\
\text { air circulation }\end{array}$ \\
\hline $\begin{array}{l}\text { Ward } \\
\text { Thompson } \\
\text { et al. (2014) } \\
\text { England, } \\
\text { Scotland and } \\
\text { Wales, } \\
\text { United } \\
\text { Kingdom }\end{array}$ & $\begin{array}{l}\text { Quasi- } \\
\text { experiment: } \\
\text { controlled, } \\
\text { pre-post } \\
\text { design }\end{array}$ & $\begin{array}{l}\text { Mean age } 75 \text { years; } \\
44 \% \text { male; } 22.5 \% \\
\text { non-white British }\end{array}$ & $\begin{array}{l}\mathrm{n}=56 \text { residents pre } \\
\text { and } \mathrm{n}=29 \text { post } \\
\text { intervention } \\
\text { 'DIY Streets': } 9 \\
\text { intervention streets } \\
\text { located in urban areas } \\
\text { in United Kingdom. } \\
\text { Streets were made } \\
\text { safer, more attractive } \\
\text { and traffic calming } \\
\text { measures were added. }\end{array}$ & $\begin{array}{l}\text { +ve: Sig. positive } \\
\text { perceptions of } \\
\text { intervention streets } \\
\text { post-intervention } \\
(p=0.04) ; \\
\text { longitudinal } \\
\text { participants } \\
\text { perceived they } \\
\text { were sig. more } \\
\text { active post- } \\
\text { intervention } \\
(p=0.04) \text { than the } \\
\text { control group }\end{array}$ \\
\hline $\begin{array}{l}\text { Joo and } \\
\text { Kwon (2015) } \\
\text { Suwon, } \\
\text { South Korea }\end{array}$ & $\begin{array}{l}\text { Quasi- } \\
\text { experimental, } \\
\text { controlled } \\
\text { (post data } \\
\text { only) }\end{array}$ & Population $1.2 \mathrm{~m}$ & $\begin{array}{l}74 \text { sites with street } \\
\text { greenery (e.g. planter } \\
\text { boxes) installed by the } \\
\text { city council, located in } \\
\text { low-rise residential } \\
\text { areas to reduce illegal } \\
\text { dumping of household } \\
\text { garbage }\end{array}$ & $\begin{array}{l}\text { +ve: Illegal } \\
\text { dumping of } \\
\text { household garbage } \\
\text { occurred at } 55.4 \% \\
\text { of sites with } \\
\text { installed greenery } \\
\text { compared to } \\
91.9 \% \text { of sites } \\
\text { without greenery } \\
\text { installed }\end{array}$ \\
\hline
\end{tabular}

PM Particulate Matter, SES Socioeconomic status, US United States, +ve positive intervention effect, $-v e$ no intervention effect 
Mayer et al. (2012) explored whether voluntary incentives were effective at distributing storm water management throughout a small suburban catchment, and whether the number and placement of rain gardens and rain barrels were sufficient to alter the hydrology, water quality and aquatic biology of the catchment. In total, 83 rain gardens and 176 rain barrels were installed onto more than $30 \%$ of the 350 eligible residential properties in a $1.8 \mathrm{~km}^{2}$ catchment area in Ohio, USA. The intervention had an overall small but statistically significant effect of decreasing storm water quantity at the sub-watershed scale. In a similar study in the same area (Shuster and Rhea 2013; Roy et al. 2014), the installation of 81 rain gardens and 165 rain barrels at four experimental areas was compared to two control areas. In contrast,

\section{Case Study: Bristol Street Green Screens, Birmingham, England, UK}

Bristol Street in Birmingham is a dual carriageway with a wide grassed central reservation along which runs, almost continuously, a metal highway pedestrian guardrail. This greening intervention involved fitting green vegetated screens to $141 \mathrm{~m}$ of existing guardrail. Installation of the green screens was completed in 2015 costing approximately $€ 29,000$. Follow-up analysis of particulate matter $\left(\mathrm{PM}_{10}, \mathrm{PM}_{2.5}\right.$ and $\left.\mathrm{PM}_{1}\right) 2$ months post installation showed significant increases $(p<.001)$ of particulates on green screen leaves in comparison to nursery stock of the same plants. In addition to the potential air quality improvement role of the green screens, they also improve the aesthetics of the street and may benefit local businesses through increased pedestrian traffic. The green screens require minimal maintenance and through utilizing existing infrastructure may provide a cost-efficient and practical solution to increasing green space within dense urban areas (Fig. 17.3).
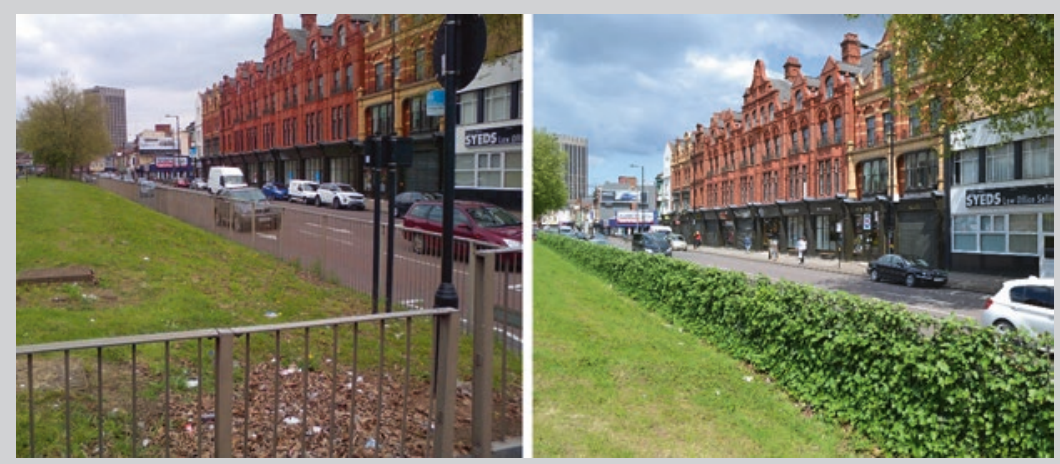

Fig. 17.3 The left panel shows Bristol Street, Birmingham in 2014 before green screen implementation and the right panel shows the street in 2016 after green screen implementation as part of the Bristol Street Green Screens Trial Project, Birmingham, UK. (Image: Chris Rance) 
Table 17.4 Summary characteristics of green infrastructure interventions

\begin{tabular}{|c|c|c|c|}
\hline Reference & Study design & Intervention & Outcome \\
\hline $\begin{array}{l}\text { Van Seters } \\
\text { et al. (2009) } \\
\text { Toronto, } \\
\text { Canada }\end{array}$ & $\begin{array}{l}\text { Quasi- } \\
\text { experiment, } \\
\text { controlled (post } \\
\text { data only) }\end{array}$ & $\begin{array}{l}\text { A } 241 \mathrm{~m}^{2} \text { green roof } \\
\text { vegetated with wildflowers } \\
\text { installed on a multi-story, } \\
\text { university building }\end{array}$ & $\begin{array}{l}\text { +ve: The green roof retained } \\
63 \% \text { more rainfall than the } \\
\text { conventional roof over the } \\
18 \text { month monitoring period }\end{array}$ \\
\hline $\begin{array}{l}\text { Carpenter and } \\
\text { Kaluvakolanu } \\
\text { (2011) } \\
\text { Michigan, } \\
\text { USA }\end{array}$ & $\begin{array}{l}\text { Quasi- } \\
\text { experiment, } \\
\text { controlled (post } \\
\text { data only) }\end{array}$ & $\begin{array}{l}\text { Extensive green roof of } \\
10.16 \mathrm{~cm} \text { depth applied to } \\
\text { the roof of a building on a } \\
\text { university campus; a green } \\
\text { roof section of } 325.2 \mathrm{~m}^{2} \\
\text { and } 929 \mathrm{~m}^{2} \text { were monitored }\end{array}$ & $\begin{array}{l}\text { +ve: Sig. higher total solids } \\
\text { concentration ( } p=0.045) \text { for the } \\
\text { green roof than the asphalt roof; } \\
\text { lower total phosphate } \\
\text { concentrations for the green roof } \\
\text { (non-sig.); green roof retained } \\
68 \% \text { of rainfall volume and } \\
\text { reduced peak discharge by an } \\
\text { average of } 89 \%\end{array}$ \\
\hline $\begin{array}{l}\text { Mayer et al. } \\
(2012) \\
\text { Ohio, USA }\end{array}$ & $\begin{array}{l}\text { Before-after- } \\
\text { control- } \\
\text { intervention } \\
\text { (BACI) } \\
\text { experimental } \\
\text { design }\end{array}$ & $\begin{array}{l}\text { Retro-fit storm water } \\
\text { management: Installation } \\
\text { of } 83 \text { rain gardens and } 176 \\
\text { rain barrels onto more than } \\
30 \% \text { of the } 350 \text { eligible } \\
\text { residential properties } \\
\text { through an incentivised } \\
\text { auction }(2007-2008)\end{array}$ & $\begin{array}{l}\text { +ve: Intervention had an overall } \\
\text { small but sig. effect of } \\
\text { decreasing storm water quantity } \\
\text { at the sub watershed scale }\end{array}$ \\
\hline $\begin{array}{l}\text { Fassman-Beck } \\
\text { et al. (2013) } \\
\text { Auckland, } \\
\text { New Zealand }\end{array}$ & $\begin{array}{l}\text { Quasi- } \\
\text { experiment, } \\
\text { controlled (post } \\
\text { data only) }\end{array}$ & $\begin{array}{l}\text { A } 500 \mathrm{~m}^{2} \text { extensive green } \\
\text { roof installed on a council } \\
\text { civic centre }\end{array}$ & $\begin{array}{l}\text { +ve: } 57 \% \text { retention of rain water } \\
\text { in comparison to control }\end{array}$ \\
\hline $\begin{array}{l}\text { Shuster and } \\
\text { Rhea (2013), } \\
\text { Roy et al. } \\
\text { (2014) } \\
\text { Ohio, USA }\end{array}$ & $\begin{array}{l}\text { Before-after- } \\
\text { control- } \\
\text { intervention } \\
\text { (BACI) } \\
\text { experimental } \\
\text { design }\end{array}$ & $\begin{array}{l}\text { Retro-fit storm water } \\
\text { management: Installation } \\
\text { of } 81 \text { rain gardens and } 165 \\
\text { rain barrels onto } 30 \% \text { of } \\
\text { properties through an } \\
\text { incentivised auction } \\
\text { (2007-2008) at } 4 \\
\text { experimental } \\
\text { subcatchments }\end{array}$ & $\begin{array}{l}\text {-ve: No sig. difference between } \\
\text { control and experimental sites } \\
\text { with regards to stream water } \\
\text { quality, periphyton, and } \\
\text { macroinvertebrate metrics } \\
\text { +ve: Small sig. decrease in } \\
\text { runoff volume in treatment } \\
\text { subcatchments }\end{array}$ \\
\hline $\begin{array}{l}\text { Kondo et al. } \\
(2015) \\
\text { Philadelphia, } \\
\text { PA, USA }\end{array}$ & $\begin{array}{l}\text { Quasi- } \\
\text { experiment: } \\
\text { difference-in- } \\
\text { difference } \\
\text { design }\end{array}$ & $\begin{array}{l}\text { Installation of green storm } \\
\text { water infrastructure at } 52 \\
\text { sites: } 152 \text { tree trenches, } 46 \\
\text { infiltration or storage } \\
\text { trenches, } 43 \text { rain gardens, } \\
29 \text { pervious pavement } \\
\text { installments, } 20 \text { bumpouts, } \\
14 \text { bio-swales, } 5 \text { storm } \\
\text { water basins, } 1 \text { wetland, } \\
\text { and } 12 \text { other }\end{array}$ & $\begin{array}{l}\text { +ve: Sig. reductions in narcotics } \\
\text { possession }(18-27 \% \text { less }) \\
(p<.01),(p<.01) \text { at varying } \\
\text { distances from treatment sites; } \\
\text { sig. reductions in narcotics } \\
\text { manufacture and burglaries; } \\
\text { non-sig. reductions in } \\
\text { homicides, assaults, thefts, } \\
\text { public drunkenness, stress } \\
\text { levels, blood pressure and } \\
\text { cholesterol }\end{array}$ \\
\hline
\end{tabular}


Table 17.4 (continued)

\begin{tabular}{|c|c|c|c|}
\hline Reference & Study design & Intervention & Outcome \\
\hline $\begin{array}{l}\text { Jarden and } \\
\text { Jefferson } \\
\text { (2016) } \\
\text { Ohio, USA }\end{array}$ & $\begin{array}{l}\text { Before-after- } \\
\text { control- } \\
\text { intervention } \\
\text { (BACI) } \\
\text { experimental } \\
\text { design }\end{array}$ & $\begin{array}{l}\text { Installation of } 91 \text { rain } \\
\text { gardens, street-connected } \\
\text { bio-retention cells and rain } \\
\text { barrels at } 2 \text { treatment } \\
\text { streets. Rain gardens ( }< \\
\left.25 \mathrm{~m}^{2}\right) \text { were installed in } \\
\text { front yards and backyards; } \\
\text { bio-retention cells } \\
\left(\sim 26-44 \mathrm{~m}^{2}\right) \text { were installed } \\
\text { between the sidewalk and } \\
\text { street }\end{array}$ & $\begin{array}{l}\text { +ve: Reduction in storm water } \\
\text { flow at the treatment streets with } \\
\text { reductions of up to } 33 \% \text { of peak } \\
\text { discharge and } 40 \% \text { of total } \\
\text { run-off volume }\end{array}$ \\
\hline $\begin{array}{l}\text { Peng and Jim } \\
(2015) \\
\text { Hong Kong, } \\
\text { China }\end{array}$ & $\begin{array}{l}\text { Quasi- } \\
\text { experiment, } \\
\text { controlled, pre } \\
\text { and post design }\end{array}$ & $\begin{array}{l}\text { A } 484 \mathrm{~m}^{2} \text { extensive green } \\
\text { roof was retrofitted on a } \\
\text { 2-story railway station }\end{array}$ & $\begin{array}{l}\text { +ve: Green roof displayed } \\
\text { cooling effects in spring, } \\
\text { summer, and fall, with slight } \\
\text { warming effects in winter }\end{array}$ \\
\hline
\end{tabular}

$B A C I$ Before-after-control-intervention, US United States, +ve positive intervention effect, $-v e$ no intervention effect

results showed no significant difference between control and intervention sites with regard to river water quality, periphyton and macroinvertebrate metrics. However, it did show a small significant decrease in runoff volume in intervention areas.

Kondo et al. (2015) investigated the effects of a range of green storm water infrastructures across 52 sites in Philadelphia on health and social outcomes using a difference-in-difference design. Installed infrastructure included 152 tree trenches, 46 infiltration/storage trenches, 43 rain gardens, 29 pervious pavements, five storm water basins, and one wetland. The comparator groups were matched control sites where no construction took place. Results showed significant reductions in narcotics possession $(18-27 \%$ less; $p<0.01)$, narcotics manufacture and burglaries. There were non-significant reductions in homicides, assaults, thefts and public drunkenness. In addition, there were negative, non-significant effects on stress levels and increased reporting of high blood pressure and cholesterol.

Jarden and Jefferson (2016) found a significant reduction in storm water flow at the intervention sites with reductions of up to $33 \%$ of peak discharge and $40 \%$ of total run-off volume. The intervention involved provision of 91 rain gardens $(<$ $\left.25 \mathrm{~m}^{2}\right)$, street-connected bio-retention cells $\left(\sim 26-44 \mathrm{~m}^{2}\right)$ and rain barrels on two streets. Each intervention street had a matched control street $(n=4)$ of similar size, drainage area and characteristics.

Van Seters et al. (2009) found that the green roof on a building in Toronto, Canada $\left(241 \mathrm{~m}^{2}\right)$ retained $63 \%$ more rainfall than the conventional (bitumen) roof over an 18-month monitoring period. In a similar study in Michigan, USA, Carpenter and Kaluvakolanu (2011) investigated the effects of an extensive green roof $\left(325.2 \mathrm{~m}^{2}\right.$ and $\left.929 \mathrm{~m}^{2}\right)$ on a university building compared to a stone-ballasted roof and an asphalt roof. Results showed that the green roof retained $68 \%$ of rainfall volume and reduced peak discharge by an average of $89 \%$. Also, there were signifi- 
cantly higher total solids concentration $(p=0.045)$ for the green roof than for the asphalt roof. Finally, Fassman-Beck et al. (2013) found that a green roof $\left(500 \mathrm{~m}^{2}\right.$ on a council civic centre) retained $57 \%$ of rain water in comparison to control (bitumen roof). All of these studies were quasi-experiments that collected postimplementation data only.

Peng and Jim (2015) found that a green roof displayed significant cooling effects in spring, summer and autumn, with slight warming effects in winter, in a suburban area in Hong Kong compared to a bare roof control site.

\subsubsection{Impact of Urban Green Space Interventions on Equity Factors}

There is currently too little evidence to enable us to draw firm conclusions regarding the impact of urban green space interventions on a range of equity indicators, for example those from disadvantaged backgrounds, migrants, the elderly, children, and those with disabilities. Twenty studies were based in disadvantaged neighbourhoods, with relatively mixed supporting evidence for urban green space interventions. For those studies that did show a positive intervention effect in disadvantaged neighbourhoods there is, however, insufficient reported information on whether the community used, or indeed, benefitted from, the urban green space interventions. Previous research demonstrating that urban green space may be 'equigenic' (Mitchell et al. 2015) (i.e. health benefits associated with access to green space are strongest among those in disadvantaged populations) suggests that this is an important area for future research.

\subsection{Lessons Learned and Key Considerations}

In summary, there was promising evidence to support the provision of urban green space interventions for environmental, health and well-being effects. In particular, there was strong evidence for park-based interventions employing a dual approach (i.e. a physical change to the urban green space and promotion/marketing programmes) particularly for increasing park use and physical activity; greening of vacant lots for health and well-being (e.g. reduction in stress) and social (e.g. reduction in crime, increased perceptions of safety) benefits; greening of urban streets particularly for environmental benefits (e.g. increased biodiversity, reduced air pollution, reduction in illegal dumping); and roof gardens for managing storm water impacts. There was promising evidence to support the provision of roof gardens for environmental benefits (temperature), which has an impact on climate change. 


\section{Case Study: Woods in and Around Towns, Multiple Locations, Scotland, UK}

Led by Forestry Commission Scotland, this greening intervention targets deprived urban areas within Scotland. The intervention aims to enhance quality of life for local residents by restoring nearby wooded green spaces and improving access to these sites. The intervention sites undergo practical upgrades such as creating and maintaining paths and trails, providing seating and resting areas, installing signs and trail 'guideposts' and implementing initiatives to improve the safety of the sites through designing and maintaining paths with a clear line of sight. Social engagement is also a key component, with intervention sites hosting organised community events such as group walks, conservation events and family fun days. Analysis of crosssectional data from residents living with $500 \mathrm{~m}$ of an intervention site has shown significant increases in visits to the green space, improved attitudes towards using the green space for physical activity, and greater perceptions of safety in comparison to a control site. Through implementing interventions in deprived urban areas this intervention helps to promote equity and provide health outcomes for those who are likely to benefit the most from green space access (Fig. 17.4).
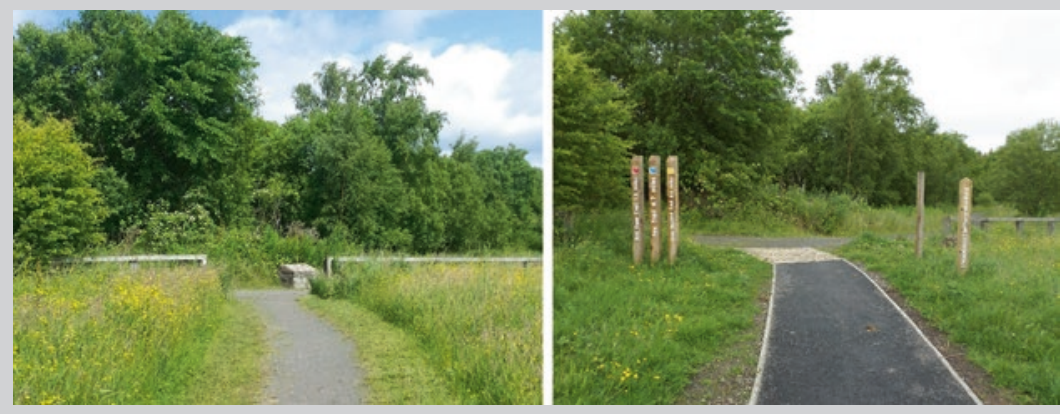

Fig. 17.4 The left panel shows the entrance to greenspace before intervention implementation and the right panel shows post intervention implementation as part of the Woods in and Around Towns programme, Scotland, UK. (Image: Left panel: Eva Silveirinha de Oliveira, Right Panel: Sara Tilley OPENspace Research Centre)

There was inconclusive evidence to support urban greenways or trails regardless of whether there were promotion and/or marketing activities to encourage use of the greenway/trails. There was limited evidence for park-based interventions that only involved physical change to the urban green space (i.e. they did not include 
programmes to promote the use of the green space), including pocket parks for health and well-being benefits, and no evidence (i.e. an absence of studies) for green walls, allotments/community gardens and urban agriculture-based interventions. There was a lack of evidence regarding adverse or unintended consequences, the long-term impact, economic benefits or the differential impacts of urban green space interventions on various equity indicators. There was also a lack of studies from low income countries. None of the studies directly assessed their impact on climate change. This could be due to inadequate observation time to detect such changes.

The next section outlines recommendations for practitioners (including urban planners, urban designers, landscape architects, civil engineers, transport engineers, property developers and public health professionals), policy-makers and researchers regarding intervening in urban green space. These recommendations were informed by the evidence review, case studies and discussions at a WHO expert working group on urban green space interventions.

\subsubsection{Practice Recommendations}

The following section builds on the previous recommendations by the WHO (2006) and NICE (2018), Public Health England (2014) and Institute for European Environmental Policy (IEEP) (2016), and also broadens these recommendations to incorporate other health, social and environmental outcomes.

The following factors should be considered when designing urban green space interventions:

1. Given the complex social and economic dynamics that occur at scale, implementation of green infrastructure requires both a multi-disciplinary (urban planning, landscape architecture, civil engineering, ecology, environmental science, urban design, public health, health economics, environmental science) and multi-sector (academic, government, nongovernmental organizations, private sector) approach.

2. Urban green space interventions should be designed with foreseen long-term impacts from the outset. Those responsible for planning and delivering interventions should 'design-in' components that specifically focus on long-term health, social and environmental effects, ensuring to take direction from the large and conclusive cross-sectional evidence base in their intervention design.

3. Local communities, and indeed different subgroups within these communities, use urban green space in a variety of ways. Future interventions need to consider how the green space may be used and what the needs of the local community are.

4. Engage the local community throughout the design process and across the life course (i.e. children to older adults) to ensure that their needs are incorporated into the intervention. This will also encourage community to take ownership for the urban green space and its future management and maintenance at a commu- 
nity level. Examples of community engagement processes include group workshops, roundtable discussions and charrettes.

5. Need to design urban green space interventions that incorporate and maximize health, environmental and social benefits.

6. Need to use a dual approach that incorporates promotion and marketing of urban green space as well as changing the physical environment (i.e. more complex than 'build it and they will come'), particularly for health and social benefits.

7. Local practitioners need to actively engage with the evaluation process, for example by engaging with local universities, organisations and the local community.

\subsubsection{Policy Recommendations}

Providing and protecting urban green space presents a significant policy opportunity to improve multiple facets of quality of life and the environment with welldeveloped and sensitive urban green space interventions. Whilst the evidence summarised here and in other reviews is sometimes mixed, there is a preponderance generally supporting the association between urban green space and health, wellbeing, and social and environmental outcomes. Policy-makers must also ensure that any provision or improvement of urban green space is done so through an 'equity lens'. The few published economic evaluations of urban green space interventions are positive. Bird et al. (2014) suggest significant financial savings could be made as a result of increased numbers of people walking and cycling. Similarly, a modelling study suggested that effectiveness estimates as low as a $2 \%$ gain in population physical activity levels would be cost-effective ( $£ 18,411$ /disability-adjusted lifeyear) (Dallat et al. 2014). Although the direct health gains are predicted to be small for any individual, summed over an entire population they are substantial (e.g. health value of physical activity in natural environments in England has been estimated at $£ 2.2 \mathrm{bn} /$ year) (White et al. 2016).

\subsubsection{Research Recommendations}

Findings from the recent WHO Regional Office for Europe report (2016) demonstrate substantial evidence to support the association between urban green space for environmental, health and well-being impacts, alongside suggested mechanisms of action. We must now move towards intervention-based research that will help policy-makers and practitioners. Findings from the evidence review suggest that areas in need of specific attention include research investigating the impact of urban green space interventions on equity indicators and economic factors (for more information, see Kabisch, Chap. 5 this volume). Research should also move beyond assessing the effects of such interventions on physical activity and usage, towards 
mental and social measures. This type of research has direct policy implications. Research is needed on the impact of interventions in a variety of green space settings, including low- and middle-income countries. Due to the scarcity of the evidence base, research on the effects of urban green space interventions on climate change and biodiversity are required. It is imperative that research is provided in a timely and accessible manner, which has implications for current publication and funding models. It is important to note the significant cost in undertaking this type of research. Researchers, practitioners and policy-makers should work together to devise novel strategies to ensure cost-effective and timely research processes, for example, exploring the use of 'virtual' research experiments. Researchers should develop relationships with key stakeholders who are responsible for urban green space provision and maintenance, for example, local authorities and housing associations, thus enabling opportunities for rigorous evaluations of urban green space interventions.

There is a considerable gap in the theoretical basis to guide intervention approaches, and further, the current intervention approaches largely negate the large and conclusive cross-sectional evidence base. Future studies should include a more complete description of their intervention strategies and logic models that describe the assumed causal pathways by which they affect the outcomes in order to better understand the underpinning theoretical mechanisms and improve future intervention design. The intervention processes logic model should also be used to inform and design the evaluation approach.

\subsection{Conclusions}

Urban green space cannot be seen in isolation from other local government priorities such as transport and housing. It must be framed holistically and viewed as a complex system in which the interplay between physical, economic, social and natural ecosystems affects health, behaviours and communities. The growing diversity of our towns and cities is transforming how green space is required and negotiated for health, well-being, and social and environmental benefits. Preserving and enhancing existing green spaces, and creating new green spaces, is critical. Significant urban green space investment is made worldwide, and many researchers and policy-makers alike have gradually shown increased support to implement costefficient and effective urban green space interventions to improve population-level health, well-being, social and environmental factors. Urban green space interventions can deliver health, social and environmental benefits for all population groups - and particularly among lower socioeconomic status groups. There are very few - if any - other public health interventions that can achieve all of this.

Acknowledgements Funding for this work was provided by the WHO Regional Office for Europe, based on a project grant from the German Federal Ministry for the Environment, Nature Conservation, Building and Nuclear Safety. The work draws on discussion at a WHO expert panel meeting in September 2016 on urban green space interventions. 


\section{References}

Anderson PML, Avlonitis G, Ernstson H (2014) Ecological outcomes of civic and expert-led urban greening projects using indigenous plant species in Cape Town, South Africa. Landsc Urban Plan 127:104-113

Bird E, Powell J, Ogilvie D et al (2014) Health economic assessment of walking and cycling interventions in the physical environment: Interim findings from the iConnect study. Paper presented at the South West Public Health Scientific conference, Weston-Super-Mare, UK, 5 Feb 2014

Bohn-Goldhaum E, Phongsavan P, Merom D et al (2013) Does playground improvement increase physical activity among children? A quasi-experimental study of a natural experiment. J Environ Public Health 2013:109841

Branas CC, Cheney RA, MacDonald JM et al (2011) A difference-in-differences analysis of health, safety, and greening vacant urban space. Am J Epidemiol 174:1296-1306

Brand C, Goodman A, Ogilvie D (2014) Evaluating the impacts of new walking and cycling infrastructure on carbon dioxide emissions from motorized travel: a controlled longitudinal study. Appl Energy 128:284-295

Burbidge SK, Goulias KG (2009) Evaluating the impact of neighborhood trail development on active travel behavior and overall physical activity of suburban residents. Transp Res Rec J Transp Res Board 2135:78-86

Carpenter DD, Kaluvakolanu P (2011) Effect of roof surface type on storm-water runoff from fullscale roofs in a temperate climate. J Irrig Drain Eng 137:161-169

Clark S, Bungum T, Shan G et al (2014) The effect of a trail use intervention on urban trail use in southern Nevada. Prev Med 67:S17-S20

Cohen DA, Golinelli D, Williamson S et al (2009a) Effects of park improvements on park use and physical activity: policy and programming implications. Am J Prev Med 37:475-480

Cohen DA, Sehgal A, Williamson S et al (2009b) New recreational facilities for the young and the old in Los Angeles: policy and programming implications. J Public Health Policy 30:S248-S263

Cohen DA, Marsh T, Williamson S et al (2012) Impact and cost-effectiveness of family fitness zones: a natural experiment in urban public parks. Health Place 18:39-45

Cohen DA, Han B, Derose KP et al (2013) Physical activity in parks: a randomized controlled trial using community engagement. Am J Prev Med 45:590-597

Cohen DA, Marsh T, Williamson S et al (2014) The potential for pocket parks to increase physical activity. Am J Health Promot 28:S19-S26

Cranney L, Phongsavan P, Kariuki M et al (2016) Impact of an outdoor gym on park users' physical activity: a natural experiment. Health Place 37:26-34

Dallat MA, Soerjomataram I, Hunter RF et al (2014) Urban greenways have the potential to increase physical activity levels cost-effectively. Eur J Pub Health 24:190-195

Droomers M, Jongeneel-Grimen B, Kramer D et al (2015) The impact of intervening in green space in Dutch deprived neighbourhoods on physical activity and general health: results from the quasi-experimental URBAN40 study. J Epidemiol Community Health 70:147-154

Evenson KR, Herring AH, Huston SL (2005) Evaluating change in physical activity with the building of a multi-use trail. Am J Prev Med 28:177-185

Fassman-Beck E, Voyde E, Simcock R, et al (2013) 4 Living roofs in 3 locations: does configuration affect runoff mitigation? Journal of Hydrology 490:11-20

Fitzhugh EC, Bassett DR, Evans MF (2010) Urban trails and physical activity: a natural experiment. Am J Prev Med 39:259-262

Frumkin H, Bratman GN, Breslow SJ et al (2017) Nature contact and human health: a research agenda. Environ Health Perspect 125:075001-075001

Garvin EC, Cannuscio CC, Branas CC (2013) Greening vacant lots to reduce violent crime: a randomised controlled trial. Inj Prev 19:198-203 
Goodman A, Sahlqvist S, Ogilvie D et al (2014) New walking and cycling routes and increased physical activity: one- and 2-year findings from the UK iConnect study. Am J Public Health 104:e38-e46

Gubbels JS, Kremers SP, Droomers M et al (2016) The impact of greenery on physical activity and mental health of adolescent and adult residents of deprived neighborhoods: a longitudinal study. Health Place 40:153-160

Institute for European Environmental Policy (IEEP) (2016) The health and social benefits of nature and biodiversity protection stakeholder workshop, 27-28 January 2016

Jarden KM, Jefferson AJ, Grieser JM (2016) Assessing the effects of catchment-scale urban green infrastructure retrofits on hydrograph characteristics. Hydrol Process 30:1536-1550

Jin S, Guo J, Wheeler S et al (2014) Evaluation of impacts of trees on PM2.5 dispersion in urban streets. Atmos Environ 99:277-287

Joo Y, Kwon Y (2015) Urban street greenery as a prevention against illegal dumping of household garbage-a case in Suwon, South Korea. Urban For Urban Green 14:1088-1094

King DK, Litt J, Halec J et al (2015) 'The park a tree built': evaluating how a park development project impacted where people play. Urban For Urban Green 14:293-299

Kondo MC, Low SC, Henning J et al (2015) The impact of green stormwater infrastructure installation on surrounding health and safety. Am J Public Health 105:e114-e121

Mayer A, Shuster WD, Beaulieu J et al (2012) Building green infrastructure via citizen participation: a six-year study in the Shepherd Creek (Ohio). Environ Pract 14:57-67

Mitchell RJ, Richardson EA, Shortt NK et al (2015) Neighborhood environments and socioeconomic inequalities in mental Well-being. Am J Prev Med 49:80-84

National Institute for Health and Care Excellence (NICE) (2018) Physical activity and the environment. https://www.nice.org.uk/guidance/ng90. Accessed 22 May 2018

New South Wales Department of Health (2002) The effect of park modifications and promotion on physical activity participation. Summary report

Peng LLH, Jim CY (2015) Seasonal and diurnal thermal performance of a subtropical extensive green roof: the impacts of background weather parameters. Sustainability 7:11098-11113

Peschardt KK, Stigsdotter UK (2014) Evidence for designing health promoting pocket parks. Archnet-IJAR 8:149-164

Public Health England (2014) Local action on health inequalities: Improving access to green spaces. Health Equity Evid Rev 8. https://www.gov.uk/government/uploads/system/uploads/ attachment_data/file/357411/Review8_Green_spaces_health_inequalities.pdf. Accessed 22 May 2018

Quigg R, Reeder AI, Gray A et al (2011) The effectiveness of a community playground intervention. J Urban Health 89:171-184

Roy AH, Rhea LK, Mayer AL et al (2014) How much is enough? Minimal responses of water quality and stream biota to partial retrofit stormwater management in a suburban neighborhood. PLoS One 17:e85011

Sahlqvist S, Goodman A, Cooper AR et al (2013) Change in active travel and changes in recreational and total physical activity in adults: longitudinal findings from the iConnect study. Int J Behav Nutr Phys Act 10:28

Shuster WD, Rhea LK (2013) Catchment-scale hydrologic implications of parcel-level stormwater management (Ohio USA). J Hydrol 485:177-187

Slater S, Pugach O, Lin W et al (2016) If you build it will they come? Does involving community groups in playground renovations affect park utilization and physical activity? Environ Behav 48:246-265

South EC, Kondo MC, Cheney RA et al (2015) Neighborhood blight, stress, and health: a walking trial of urban greening and ambulatory heart rate. Am J Public Health 105:909-913

Strohbach MW, Lermana SB, Warren PS (2013) Are small greening areas enhancing bird diversity? Insights from community-driven greening projects in Boston. Landsc Urban Plan 114:69-79

Tester J, Baker R (2009) Making the playfields even: evaluating the impact of an environmental intervention on park use and physical activity. Prev Med 48:316-320 
Van Seters T, Rocha L, Smith D et al (2009) Evaluation of green roofs for runoff retention, runoff quality, and leachability. Water Qual Res J Can 44:33-47

Veitch J, Ball K, Crawford D et al (2012) Park improvements and park activity: a natural experiment. Am J Prev Med 42:616-619

Ward Thompson C, Roeb J, Aspinall P (2013) Woodland improvements in deprived urban communities: what impact do they have on people's activities and quality of life? Landsc Urban Plan 118:79-89

Ward Thompson C, Curl A, Aspinall P et al (2014) Do changes to the local street environment alter behaviour and quality of life of older adults? The 'DIY streets' intervention. Br J Sports Med 48:1059-1065

West ST, Shores KA (2011) The impacts of building a greenway on proximate residents' physical activity. J Phys Act Health 8:1092-1097

White MP, Elliott LR, Taylor T et al (2016) Recreational physical activity in natural environments and implications for health: a population based cross-sectional study in England. Prev Med 91:383-388

WHO Regional Office for Europe (2016) Urban green spaces and health. WHO Regional Office for Europe, Copenhagen, Denmark

WHO Regional Office for Europe (2017) Urban green space interventions and health. WHO Regional Office for Europe, Copenhagen, Denmark

World Health Organisation (WHO) (2006) Promoting physical activity and active living in urban environments. The role of local governments. The solid facts. World Health Organization Europe, WHO Regional Office for Europe, Copenhagen

Open Access This chapter is licensed under the terms of the Creative Commons Attribution 4.0 International License (http://creativecommons.org/licenses/by/4.0/), which permits use, sharing, adaptation, distribution and reproduction in any medium or format, as long as you give appropriate credit to the original author(s) and the source, provide a link to the Creative Commons license and indicate if changes were made.

The images or other third party material in this chapter are included in the chapter's Creative Commons license, unless indicated otherwise in a credit line to the material. If material is not included in the chapter's Creative Commons license and your intended use is not permitted by statutory regulation or exceeds the permitted use, you will need to obtain permission directly from the copyright holder.

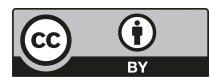

